\title{
Precipitation Characteristics of Warm Season Weather Types in the Southeastern United States of America
}

\author{
Jian-Hua Qian *, Brian Viner, Stephen Noble (D) and David Werth \\ Savannah River National Laboratory, Aiken, SC 29808, USA; brian.viner@srnl.doe.gov (B.V.); \\ stephen.noble@srnl.doe.gov (S.N.); david.werth@srnl.doe.gov (D.W.) \\ * Correspondence: jianhua.qian@srnl.doe.gov
}

Citation: Qian, J.-H.; Viner, B.; Noble, S.; Werth, D. Precipitation Characteristics of Warm Season Weather Types in the Southeastern United States of America. Atmosphere 2021, 12, 1001. https://doi.org/ $10.3390 /$ atmos 12081001

Academic Editor:

Eduardo García-Ortega

Received: 18 June 2021

Accepted: 31 July 2021

Published: 3 August 2021

Publisher's Note: MDPI stays neutral with regard to jurisdictional claims in published maps and institutional affiliations.

Copyright: (C) 2021 by the authors. Licensee MDPI, Basel, Switzerland. This article is an open access article distributed under the terms and conditions of the Creative Commons Attribution (CC BY) license (https:/ / creativecommons.org/licenses/by/ $4.0 /)$.

\begin{abstract}
Daily weather types (WTs) over the Southeast United States have been analyzed using $850 \mathrm{hPa}$ winds from reanalysis data from March to October of 1979-2019. Six WTs were obtained. WTs 1-3 represent mid-latitude synoptic systems propagating eastward. WT4 is a summer-type pattern predominantly occurring in June-August, with the center of the North Atlantic Subtropical High (NASH) along the Gulf coast in the southern United States. WT5 is most frequent from August to middle October, with the NASH pushed further north and southerly winds over the northern Great Plains. An anticyclone centered at the Carolina coast characterizes WT6, which occurs in all months but is slightly more frequent in the spring and fall, especially in October, corresponding to fair weather in the region. WTs 1, 2 and 3 can persist for only a few days. WTs 4,5 and 6 can have long spells of persistence. Besides self-persistence, the most observed progression loop is WT1 to WT2, to WT3, and then back to WT1, corresponding to eastward-propagating waves. WTs 4 and 5 are likely to show persistence, with long periods of consecutive days. WT6 usually persists but can also transfer to WT3, i.e., a change from fair weather in the Southeast U.S. to rainy weather in the Mississippi River Valley. A diurnal cycle of precipitation is apparent for each WT, especially over coastal plains. The nocturnal precipitation in central U.S. is associated with WT3. WTs 1-3 are more frequent in El Niño years, corresponding to stronger westerly wave activities and above normal rainfall in the Southeast U.S. in the spring. The positive rainfall anomaly in the Mississippi and Ohio River valley in El Niño years is also associated with more frequent WT3.
\end{abstract}

Keywords: weather types; diurnal cycle; El Niño

\section{Introduction}

Precipitation is abundant in the Southeastern United States of America (SEUS). On average, the nine states in the SEUS (Alabama, Arkansas, Florida, Georgia, Louisiana, Mississippi, North and South Carolina, and Tennessee) garner 1260-1530 mm (roughly 50-60 inches) per year of precipitation state wise, ranking from the second to the eleventh among all 50 states in the U.S.A. (North Carolina ties with Connecticut at Number 9 and Hawaii is Number 1). The topography of the Gulf and Atlantic coastal plains and Appalachian Mountains affects the spatial distribution of precipitation (detailed background will be given in Section 2). The precipitation varies with season in the SEUS, with the warm season having higher precipitation intensity than the cold season in the coastal areas while the opposite might be true in some inland areas [1]. It is also subject to extreme weather by way of torrential rain and floods and water deficits associated with long-persistent dry spells [2-5].

Statistical characteristics of daily weather types (WTs) are important aspects of climate. Because of the chaotic nature of the atmosphere [6], poorly defined initial conditions (such as the error from instrument observation of limited resolution) mean that weather forecasts lose skill after about two weeks. The boundary-forcing-problem of climate forecasts, however, may have skill for monthly or seasonal means for periods much further into the future, such as the seasonal climate outlook or forecasts of El Niño-Southern Oscillation 
(ENSO), which is mainly forced by the sea surface temperature (SST). Therefore, the climate and weather research communities take rather different approaches, with the former focusing on seasonal or monthly means while the latter dealing with short-term daily weather events. The weather-within-climate information provided by the WT analysis aims to bridge the gap between these two communities. It gives a dynamic view of climate variation in terms of day-by-day WTs.

Sheridan redeveloped a spatial synoptic classification scheme (SSC) based on station observation over North America [7]. Daily meteorological observation on each station is assessed to determine the WT at the station according to the humidity and the origin of air mass (tropical or polar). There are six WTs (dry polar, dry moderate, dry tropical, moist polar, moist moderate, and moist tropical) and a transition type. A series of daily maps, scattered with different WTs among the stations on a daily map, were then generated. The neighboring stations may or may not have the same WT on a given day; however, localized neighboring stations often share the same WT. This point wise WT analysis method has been applied to regional and global gridded reanalysis data [8]. It was also used in the study of intense precipitation events in the SEUS [3,4]. In conjunction with the SSC method, a principal component analysis and k-means clustering analysis method were also used, based on $850 \mathrm{hPa}$ and $500 \mathrm{hPa}$ geopotential heights, for the days of extreme weather with intense precipitation in multiple stations in the SEUS [3]. However, the attempt of the $\mathrm{k}$-means classification was somewhat unsuccessful to delineate the sample, probably due to the common feature of concentric low-pressure system in the SEUS during those intense precipitation days. Manual classification was used as a remedy [3].

Although the k-means method may not work well solely for the extremely intense precipitation events in a region [3], it works well by including all the days in a long period of time. For example, the k-means clustering method successfully captured the WTs in the winter [9] and autumn [10] in the Northeast U.S. and also in the tropics [11] in the past 3-4 decades. All those studies used the $850 \mathrm{hPa}$ winds of reanalysis data for the WT analysis (other variables, such as $500 \mathrm{hPa}$ heights and $200 \mathrm{hPa}$ winds, were included for testing WT clustering analysis, and they were found to be not making significant differences) $[9,12]$. Therefore, the $850 \mathrm{hPa}$ winds can be effectively used to classify the regional WTs, both in the tropics and extra-tropics. We will use the daily $850 \mathrm{hPa}$ winds for the WT analysis in the current study, focusing on the warm season in the SEUS. Here, our warm season includes boreal spring, summer and early fall, considering that we are interested in the diurnal cycle of precipitation associated with sea breezes and that sea breezes frequently occur from March to October over the coastal plains in the SEUS, as shown in a recent paper [13].

For the Atlanta metropolitan statistical area in Georgia, a WT analysis was carried out based on precipitation at 30 stations in this local area [14-17]. A principal component analysis was applied to the precipitation data, and three distinct subregions (south, northwest, and northeast) in the vicinity of Atlanta were derived with different characteristics of precipitation variability. Composite analysis corresponding to the precipitation characteristics in the three subregions near Atlanta was then carried out for the $850 \mathrm{hPa}$ and $500 \mathrm{hPa}$ geopotential height in the SEUS, respectively. In these studies, geopotential height field (reflecting geostrophic circulation in this mid-latitude area) was derived after the precipitation-based WT analysis.

It should be pointed out that the definition of our WTs is somewhat different from that of the SSC scheme $[7,8,14-17]$. The SSC scheme defines the WT on a station or a grid point perspective. However, our WT is defined as a circulation-based weather pattern/regime of a day in a certain region $[18,19]$. In our case, the WT in the whole region on any calendar day is represented by a single number, which dramatically simplifies the matter. On the other hand, our circulation-based WTs should capture the gross regional-scale synoptic feature of the day but might be at the expense of omitting localized details at some stations. Nevertheless, the circulation-based WTs were still useful for analyzing extreme precipitation, as shown in the study of extreme precipitation in the Northeast U.S. [12]. 
The purpose of the study is to understand the weather-within-climate information in the warm season in the SEUS. We will analyze the daily reanalysis and observed data to explore the spatial pattern and frequency of daily WTs in the past forty years (1979-2019). After deriving the WTs based on the $850 \mathrm{hPa}$ winds, we will examine the precipitation processes under different WTs to understand the warm season hydroclimate in the SEUS, especially the impact of sea breezes [13] on precipitation over the vast coastal plains and the role of the diurnal cycle for the precipitation in central U.S. around the Mississippi River Valley.

Section 2 describes the topography and climate background in the SEUS. The datasets and the analysis method are specified in Section 3. Results of WT analysis, and the winds, precipitation and other fields for each WT, the diurnal cycle, and the climate variability associated with ENSO from the perspective of the WTs are given in Section 4. Discussion and conclusion are drawn in Section 5 .

\section{Climate Background in the SEUS}

The terrain of the SEUS (Figure 1) comprises great variability. Coastal plains are on the southeast of the Appalachian Mountains (Virginia, North and South Carolina, and Georgia) and along the Gulf coast (Florida, Alabama, Mississippi, Louisiana). West of the Appalachian Mountains is Tennessee. The Mississippi Alluvial Plain is in the southeast and east Arkansas, while the Boston Mountains are in northwestern Arkansas.

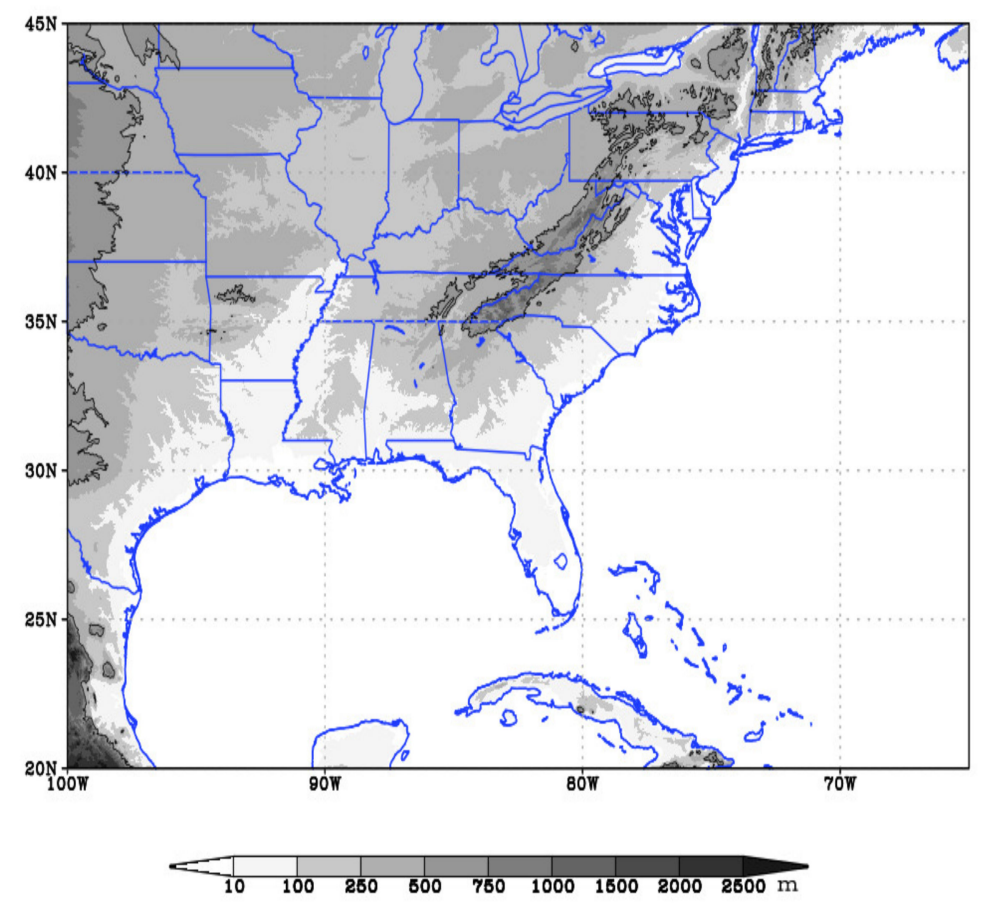

Figure 1. Terrain heights $(\mathrm{m})$ in the Southeastern United States and the adjacent region based on the United States Geological Survey (USGS) observation. Black contours show terrain heights of $500 \mathrm{~m}$.

The WTs and climate in the SEUS are closely related to the North Atlantic Subtropical High (NASH), also called the Bermuda High, which is a quasi-stationary atmospheric circulation in the lower atmosphere stretching from east of the Rocky Mountains to the North Atlantic. From winter to summer, the NASH migrates from south to north and also extends westward. Low-level southerly winds in the western part of the NASH transport moist air from the warm Gulf of Mexico, then veer toward northeast in the spring, but encroach further to the north in the summer and early fall. Within the midlatitude westerlies in the northern part of the NASH, baroclinic waves of troughs and ridges propagate eastward, corresponding to cloudy/rainy or fair-weather days, respectively. The north-south oriented Rocky Mountains and the quite flat Great Plains allow warm 
moist tropical air moving north to the northern Great Plains in the summer (and cold polar air penetrating to the Gulf coast in the winter as well). The diurnal cycle of mountainvalley winds and the associated precipitation in the summer, guided by the westerlies in the middle troposphere, form a downwind propagating precipitation system. It brings forth precipitation in the Great Plains, Midwest and the SEUS [20,21]. The direction of the precipitation propagation depends on the daily weather types. The Appalachian Mountains block cold air from the northwest, but on the eastern side of the mountains, cold air damming from the northeast can bring cold weather to the south in the winter [22,23]. The diurnal cycle of convective precipitation can also be seen over the Appalachian Mountains and the adjacent region [24].

Tropical cyclones and hurricanes strongly affect the weather in the southeast coastal plains [25-28]. The strong temperature gradient between the warm Gulf Stream off the east coast and the cold coastal land in the cold seasons also forms a baroclinic belt. This belt corresponds to the east coast storm track, with cyclones moving northeastward along the east coast, which is also in the northwest periphery of the NASH [29]. The Gulf coast garners abundant rainfall because of plenty of moisture from the warm Gulf of Mexico, forming land-sea breeze related rainfall in the warm season [3,30-33]. This precipitation system can propagate to the east coast following the southwesterly winds in the northwest periphery of the NASH.

\section{Data and Weather Typing (WT) Analysis}

\subsection{Data}

The daily $850 \mathrm{hPa}$ winds of NCEP-NCAR Reanalysis Project (NRP) [34] were used for the WT analysis. This data was chosen because it has a long record and is updated through the present. Other variables in the NRP, such as $850 \mathrm{hPa}$ geopotential height, will be used to develop composites for the different WTs.

We also need precipitation data that covers both land and seas to analyze coastal weather and climate. Thus, the satellite estimated 3-hourly precipitation data from CMORPH (NOAA Climate Prediction Center-CPC Morphing Technique, $0.25^{\circ} \times 0.25^{\circ}$, 1998-2019) [35] are used to study the diurnal cycle of precipitation.

\subsection{WT Analysis}

A domain of $100^{\circ} \mathrm{W}-65^{\circ} \mathrm{W}, 20^{\circ} \mathrm{N}-45^{\circ} \mathrm{N}$ is used for the study. This is large enough to capture regional synoptic scale weather patterns, while focusing on the region of interest. WTs are defined using a k-means clustering analysis of the $850 \mathrm{hPa}$ winds in March-October (covering the warm season and transitioning seasons) of 1979-2019. We focus on the warm season in the current study because of the diurnal cycle of the rainfall associated with sea breezes along the very long coast lines in the SEUS.

This $850 \mathrm{hPa}$ circulation field has been used both in the tropics [36,37] and extratropics [9]. The zonal and meridional components of the winds ( $u$ and $v$, respectively) are extracted from the NCEP reanalysis data. The wind components were first normalized, then put through a pre-filtering process by keeping $75 \%$ of the total variance. A set of initial seeds in the phase space were chosen for the iterative clustering analysis, with a prescribed number of clusters $(\mathrm{k})$. An iterative process was then applied to move the cluster seeds, maximizing the differences between the clusters and minimizing the differences within a cluster. A classifiability index (CI, see [9] for details) is calculated for this measure, with large $\mathrm{CI}$ indicating a better separation between clusters. The number of clusters $(\mathrm{k})$ is varied from 2 to 20 , then the $\mathrm{k}$ corresponding to the largest $\mathrm{CI}$ after the first decrease of $\mathrm{CI}$ is chosen as the optimum number of clusters. The CI for the WT analysis over the SEUS (Figure 2) shows that the daily weather in this region can be best represented by 6 clusters $(\mathrm{k}=6)$. 


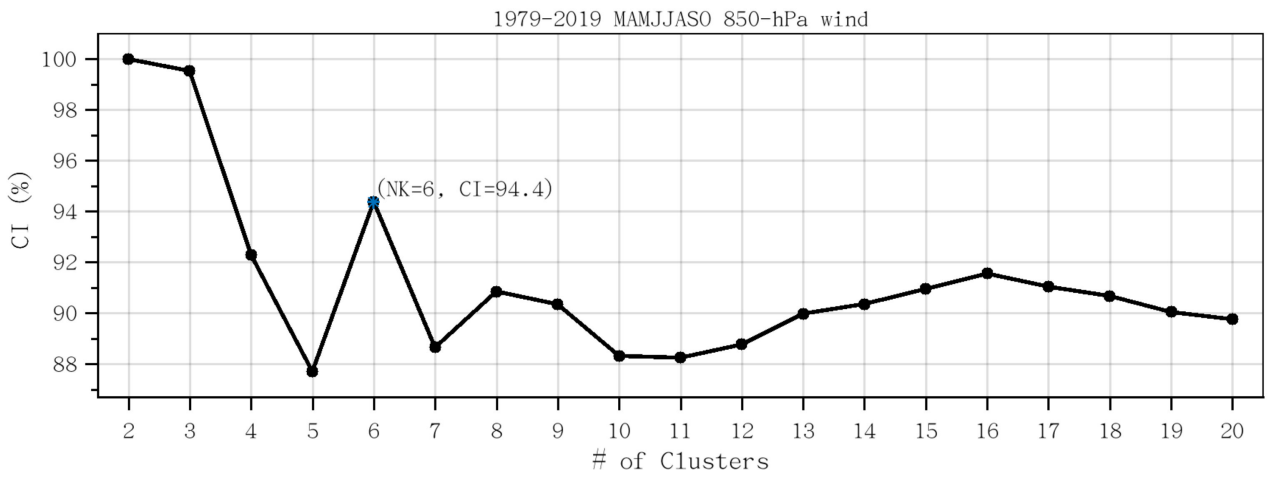

Figure 2. The classifiability index (CI) of the k-means clustering analysis using $850 \mathrm{hPa}$ zonal and meridional wind component ( $\mathrm{u}$ and $\mathrm{v})$ in the Southeast U.S. and the surrounding region $\left(100^{\circ} \mathrm{W}-65^{\circ} \mathrm{W}\right.$, $20^{\circ} \mathrm{N}-45^{\circ} \mathrm{N}$ ) in March-October, 1979-2019; the optimum number for the k-means analysis is $\mathrm{k}=6$.

Each calendar day is assigned to a cluster (an integer number from 1 to $\mathrm{k}$ ), and to each cluster is assigned a WT-the average of all days within that cluster. Each number of 1 to $\mathrm{k}$ represents a WT with its spatial pattern of circulation field. The circulation-based WT analysis method has effectively captured regional synoptic features in other regions [9-11], and we hope to see a similar result in the SEUS as will be discussed Section 4.

\section{Results}

\subsection{Weather Types (WTs) in the SEUS}

The maps of mean $850 \mathrm{hPa}$ winds for the six WTs are shown in Figure 3. In this midlatitude region, the winds are almost parallel to geopotential height contours, indicating it is quite geostrophic here. WT1 can be described as an "east coast trough" (ECT, Figure 3a) with precipitation ahead of the trough along coastal land from Florida to the mid-Atlantic coast, but with the maximum precipitation over the costal ocean along the Gulf stream. Behind the trough, it is dry in the Great Plains. Offshore northerly winds are over most of the Gulf coast where it is also quite dry. In WT2 (Figure 3b), a ridge is over the Mississippi River Valley (MRVR), with a trough and rainy area over the Atlantic Ocean near $65^{\circ} \mathrm{W}$. The southeast coast and the Great Lakes area are dry. The Great Plains get some rainfall with the moisture supplied by the southerly flow from the Gulf coast. In WT3 (Figure 3c), a trough is over the eastern Great Plains and the Mississippi and Missouri river valleys (may be called "plains trough", PT), the strong southwesterly flow east of the trough transports moisture from the Gulf of Mexico and dumps heavy rainfall in the Mississippi River Valley, while precipitation in east coast states is only moderate. In WT4 (Figure 3d), the anti-cyclonic flow in the western part of the NASH is the dominate circulation over the SEUS. The NASH extends westward from Florida to Texas. The center line of the NASH in this longitude range is off the Gulf coast running across Florida peninsula, therefore we call this WT the "Florida High Zone" (FHZ). Westerly flow is in the SEUS except Florida. There is some rainfall along the Gulf coast, Florida and southeast coast area, as well as on the windward western slope of the Appalachian Mountains. In WT5 (Figure 3e), the background circulation is still NASH, not only extended westward to Texas, but also advanced to the north to the inland. This inland high, as indicated by the anti-cyclonic circulation centered over the Ohio River valley and the Appalachians, can be called "Appalachian High" (AH). The AH is somewhat separated from the main body of the NASH in the Atlantic. The winds in the SEUS are weak and easterly. Rainfall is over the southeast coast and Florida. The southerly flows on the west periphery of the subtropical high transport moisture further north to rain in northern Great Plains. WT6 features an east coast high with strong anti-cyclonic flow centered at the Carolinas (thus called "Carolina High", CH), and quite dry here (Figure 3f). But the southwesterly flow in the mid-west states produces considerable rainfall. 


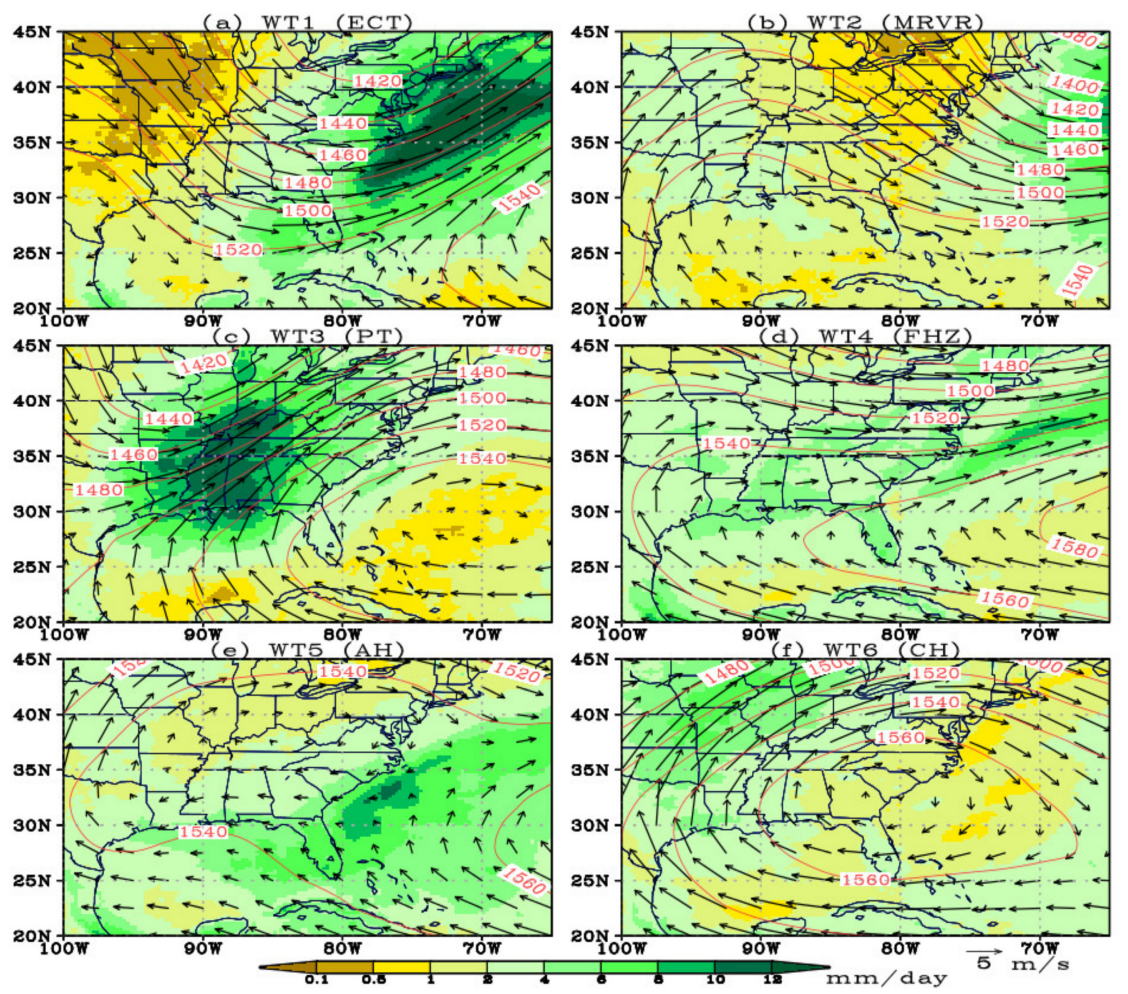

Figure 3. The average precipitation (shade), $850 \mathrm{hPa}$ winds (arrows) and geopotential height (red contours) of the six WTs. WTs 1-6 (shown in subfigures (a-f), respectively) can be briefly described as East Coast Trough (ECT), Mississippi River Valley Ridge (MRVR), Plains Trough (PT), Florida High Zone (FHZ), Appalachian High (AH), and Carolina High $(\mathrm{CH})$, respectively.

\subsection{Frequency of the WTs}

In March-October of 1979-2019 (10,045 days in total), the percentage of the total number of days with WT 1-6 was 10.2\%, 11.8\%, 10.5\%, 27.8\%, 19.4\%, and 20.3\%, respectively. The occurrence of the daily WTs through the season is shown in Figure 4 . It gives the 41-year averaged frequency of the six WTs, respectively. WTs 1, 2 and 3 (ECT, MRVR, $\mathrm{PT}$, the three least frequent WTs) sporadically occur in the early and late months. WT4 (FHZ) mostly occurs in June-August in the summer, thus it is mainly a summer WT. It is also the most frequent WT in the warm season. WT5 (AH) mostly occurs in the fall (late August-early October), thus an autumn WT. WT6 (CH) occurs almost every month, but most frequently in May-June and September and October, especially the later, typically corresponding to fair weather with an anticyclonic flow over the SEUS.

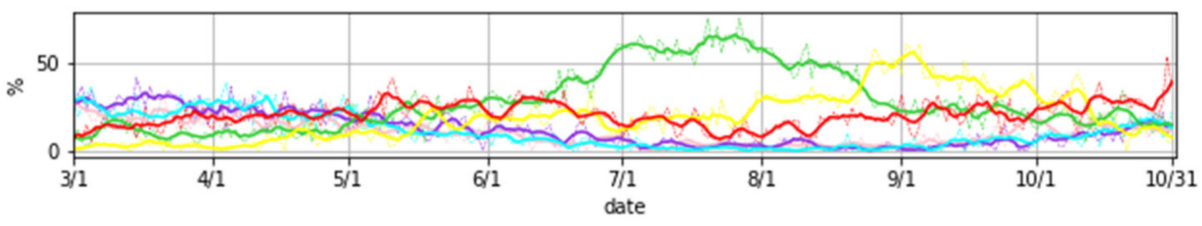

Figure 4. The 41-year (1979-2019) averaged frequency (percentage) of the six WTs (thin curves) from 1 March to 31 October (245 days/year). The thick curves are the 5-day running average. Color: WT1 (pink), WT2 (purple), WT3 (light blue), WT4 (green), WT5 (yellow), WT6 (red).

Some WTs have short persistence, and some persist (i.e., remain at that same WT) longer. Figure 5 shows that WT1, 2 and 3 (ECT, MRVR, PT) can persist for only a few days, rarely to more than five days, with the longest persistence by WT1 for nine days. WT3 never persists for more than six days. WT4, 5 and 6 (FHZ, AH, CH) can have long spells of persistence for over 10 days, especially for WT4 and WT5 (longest persistence of 20 and 
19 days, respectively); but WT6 only persists up to 12 days. Since WT6 is a dry weather type, its long persistence in May-June can cause droughts in the crop-growing season.

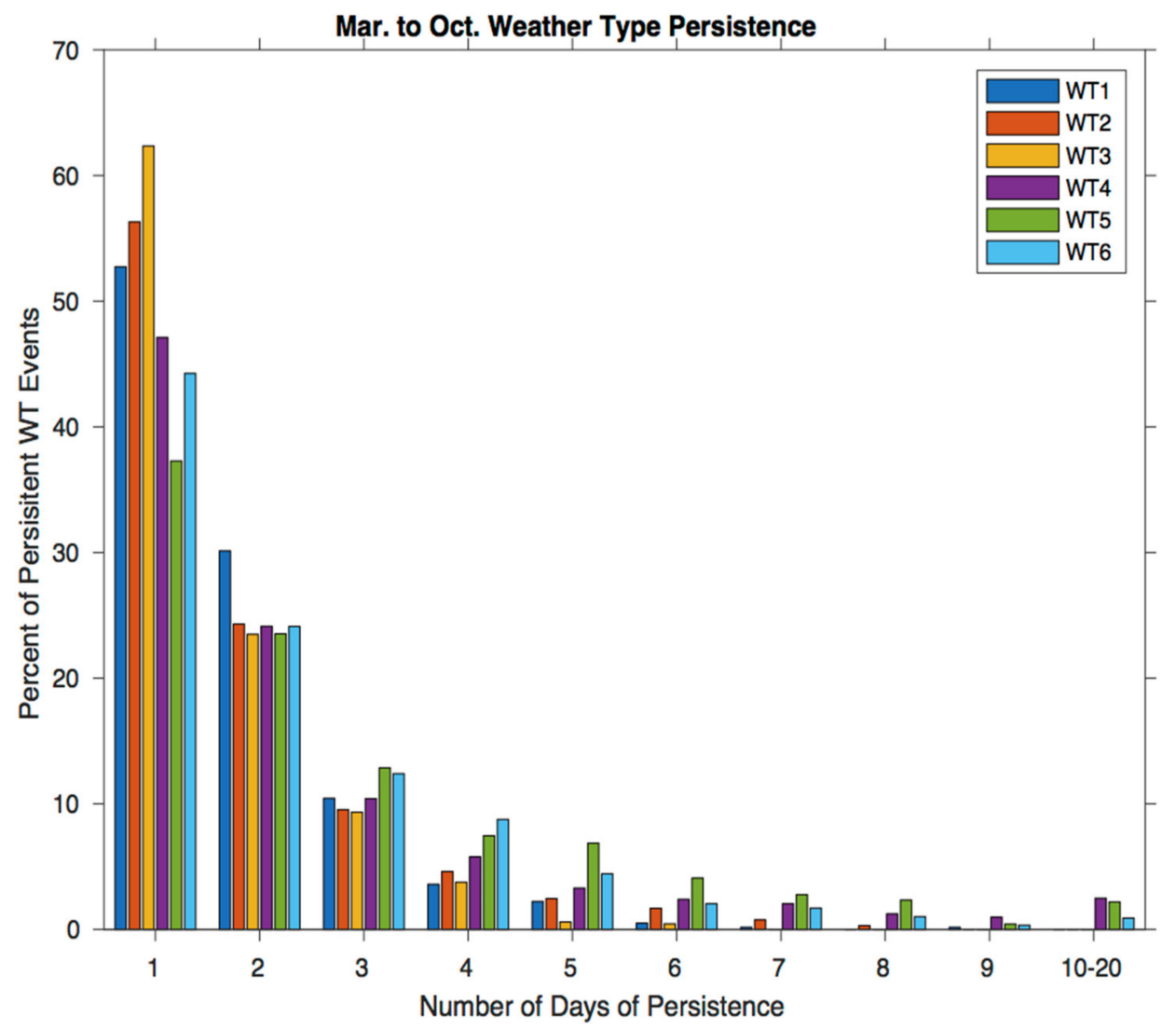

Figure 5. Persistence of the six WTs. presented by different color bars, respectively. The x-axis is the length of consecutive days with the same WT. The last group of bars are the sums of persistent events of 10 to 20 days. WT1-3 never have persistent events of over 10 days long. WT4, WT5, and WT6 have long persistence up to 20,19, and 12 days, respectively.

Besides self-persistence, the favorite progression loop is WT1 (ECT) to WT2 (MRVR), to WT3 (PT), and then back to WT1, as shown in Figure 6. By comparing the circulation patterns of these three WTs (Figure $3 \mathrm{a}-\mathrm{c}$ ), we can see the above progression loop corresponds to the eastward propagation of westerly waves. WT4 and 5 are likely to persist, respectively, with long sequence of the same WT. WT6 more likely persists, but also preferably transfers to WT3, i.e., changes from fair weather in the SEUS to a pattern of rainy weather from the Gulf coast to the mid-west in the Mississippi River Valley. Again, by comparing the circulation pattern of WT6 and WT3 (Figure 3c,f), the progression from WT6 to WT3 corresponds to the eastward retreat of the $\mathrm{CH}$, or a trough propagate from the west to the Plains.

In the cold months, when atmospheric baroclinicity is stronger, wave-like WTs (WTs1-3) are more prevalent. But the summer and autumn weather types (WT4 and 5) have longer persistence, which is somewhat like the quasi-stationary 'Mei-yu' front in May-July in East Asia [38]. The Mei-yu is more persistent because of the special topography of the Tibetan Plateau. In North America, there is no Mei-yu-like monsoonal precipitation system, but still the WTs in summer months are more persistent than those of the cold months. The circulations of WT4 (FHZ) and WT5 (AH) in the SEUS are controlled by the quasi-stationary NASH (Figure 3d,e), which might be why they are more persistent. 


\section{WT Progression (SE US)}
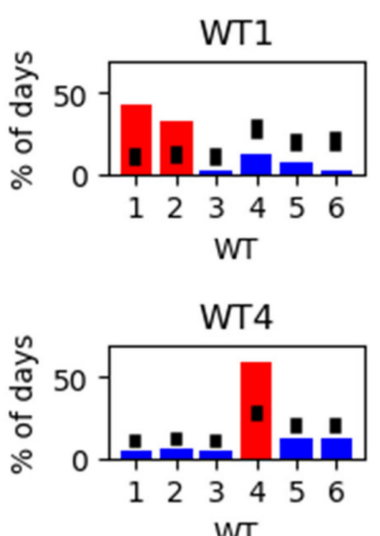

WT
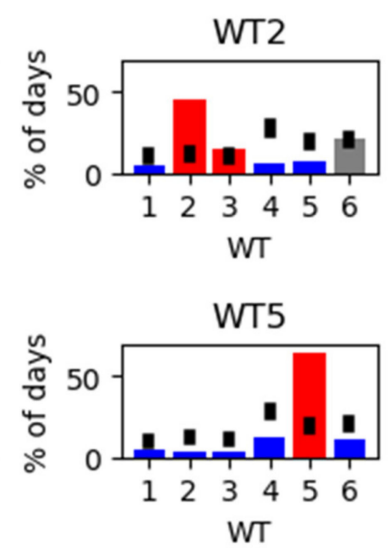
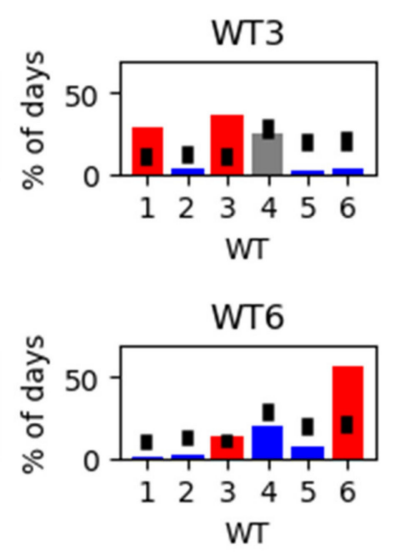

Figure 6. The progression of the WTs. The 95\% confidence interval of the WT background frequency (the occurrence of WT transition due to chance) is shown with black shading. Frequencies significantly greater than the background frequency are shown with red bars; frequencies significantly less than the background bars are shown with blue bars.

\subsection{Diurnal Cycle of Precipitation for the Six WTs}

The SEUS has extensive coastlines, and sea breezes have a strong impact on the precipitation in the coastal plains during the warm months. Analyses of the diurnal cycle of precipitation help to understand the spatial distribution of precipitation. Based on the 3-hourly quarter-degree CMORPH precipitation estimation, the diurnal cycle of precipitation for each of the six WTs is calculated.

In WT1(ECT) (Figure 7), the maximum rainy area is off the east coast (in front of an east coast trough shown in Figure 3a). It is remarkable to note that the diurnal cycle of precipitation is quite strong even over the ocean. The peak rainfall is in the morning over the ocean (1:00-10:00 AM Local Daylight Time (LDT) in Eastern U.S. which is $5 \mathrm{~h}$ later than the UTC). This oceanic rain belt is roughly over the Gulf stream area. The east-west cross-section (figure not shown) indicates that the rain belt propagates eastward at a speed of about 5 degrees of longitude per day, like the magnitude of $850 \mathrm{hPa}$ zonal wind speed of $5 \mathrm{~m} / \mathrm{s}$ as shown in Figure 3a. Therefore, it is the eastward advection by synoptic winds. Over coastal lands, such as the headlands of North Carolina and the Virginia coast, peak rainfall occurs in the evening (19:00-22:00 LDT) and lingers at night (22:00-4:00 LDT). In the Florida Peninsula, the diurnal cycle is not very strong as WT1 mostly occurs in the early spring when the area is not very warm yet. We can still see more rainfall during the daytime (10-19 LDT) than overnight (22-07 LDT). In the morning (07-13 LDT), rainfall moving from west coast of Florida following the prevalent westerlies in Florida in WT1. In 13-16 LDT, the maximum rainfall is over Central and South Florida. Rainfall moves to the east coast of Central and South Florida in the late afternoon (16-19 LDT). The diurnal cycle is weak along the Gulf coast. But in the land area of the SEUS, even though the diurnal cycle is quite weak, more rainfall is over land right after sunset (19-22 LDT). The diurnal cycle of precipitation in WT2 (MRVR) is weak (Figure 8), but a rainfall peak occurs in the afternoon (13:00-19:00 LDT), especially in Gulf coast states and Florida. Different from the Gulf coastal plain, the timing of the peak rainfall is after midnight (01-07 LDT) over the border of Oklahoma, Arkansas, Kansas and Missouri. This may be caused by the convergence of downslope mountain winds to the basin (Figure 1) overnight. 

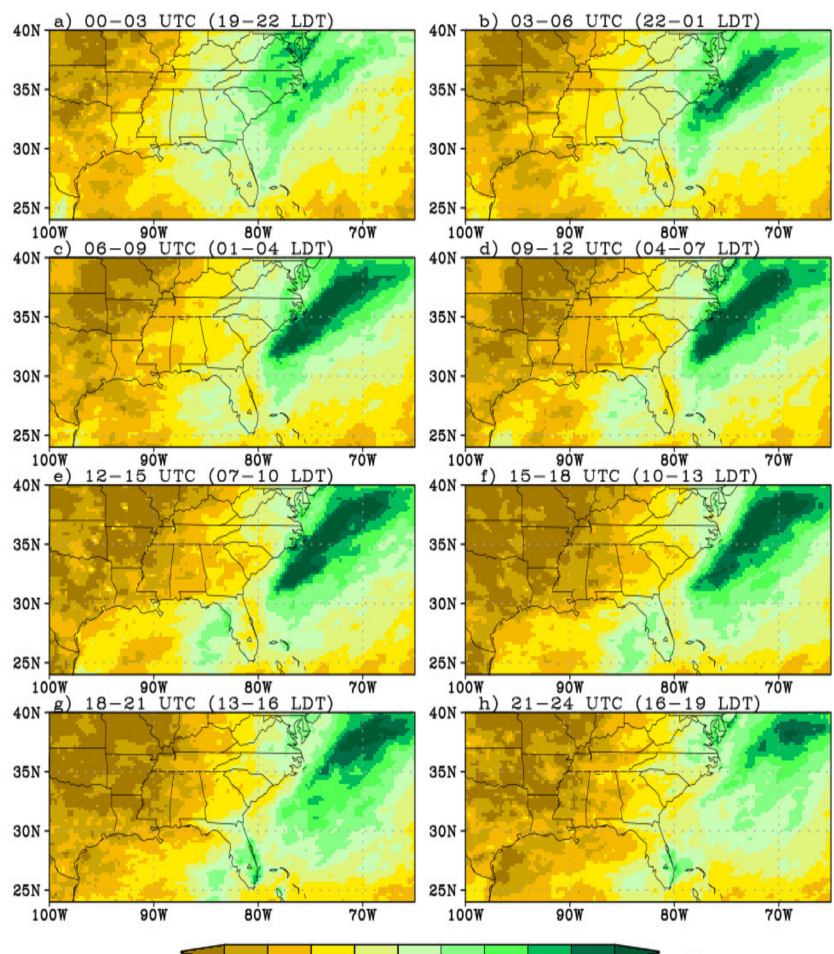

Figure 7. Diurnal cycle of CMORPH precipitation for WT1. LDT: U.S. eastern time, i.e., local daylight time at $75^{\circ} \mathrm{W}$, which is five hours later than the Coordinated Universal Time (UTC). Subfigures (a-h) show 3-hourly average precipitation rate (mm/day) in 00-03 UTC, 03-06 UTC, 06-09 UTC, 09-12 UTC, 12-15 UTC, 15-18 UTC, 18-21 UTC, and 21-24 (or 00) UTC, respectively.
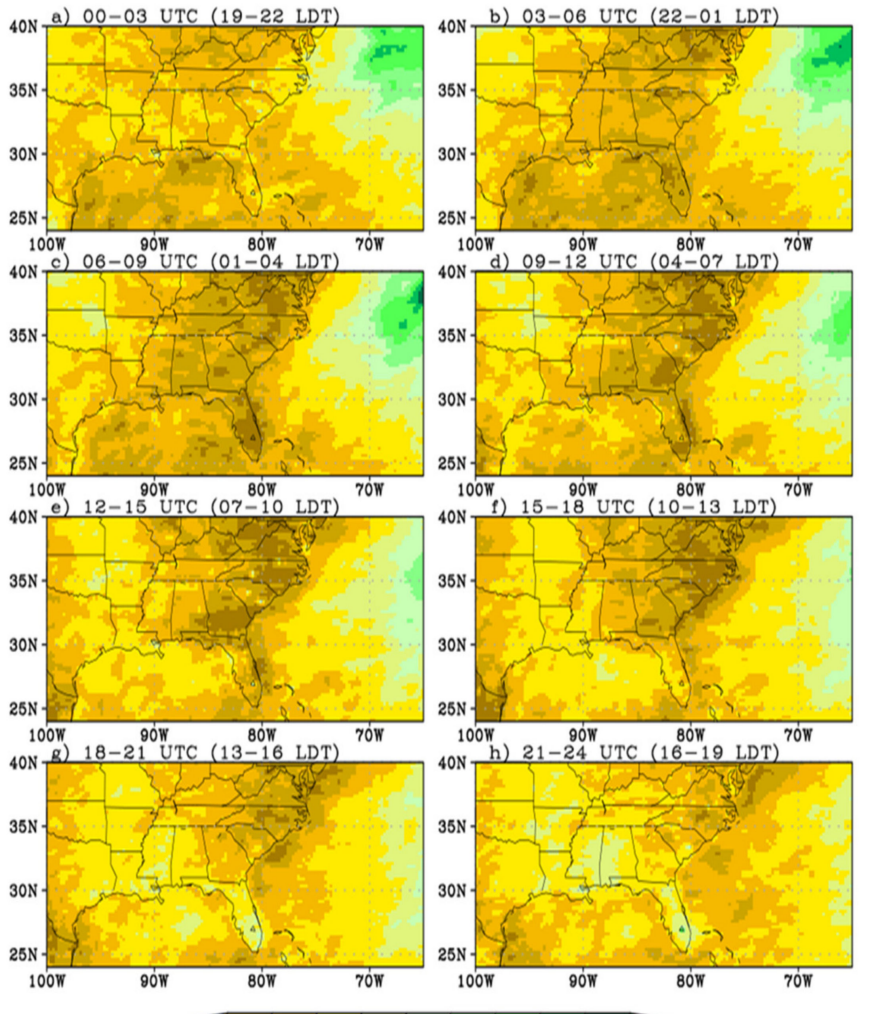

Figure 8. Same as Figure 7, but for WT2. 
In WT3 (PT) (Figure 9), the diurnal cycle of rainfall is strong in the middle Mississippi River and Ohio River valleys, with heavy rainfall from evening to early morning (19:00-4:00 LDT, peak in 22:00-01:00 LDT with the rain rate of about $16 \mathrm{~mm} /$ day). This may be related to the nocturnal low-level jet [39] that transports moisture to fuel precipitation. Over the Gulf coast, maximum rainfall is during daytime, moving from coastal waters to coastal plains (07-19 LDT). The maximum rain rate off the Alabama coast $(16 \mathrm{~mm} /$ day) is slightly larger than that over the coastal land $(14 \mathrm{~mm} /$ day), as indicated in a north-south cross-section along $87.5^{\circ} \mathrm{W}$ belt (figure not shown). The precipitation from the Gulf coast in 13-16 LDT expands downwind (according to the wind direction shown in Figure 3c) toward Georgia and South Carolina, and a local maximum rainy area is found near the city of Savannah on the east coast close to the state line in 16:00-19:00 LDT.

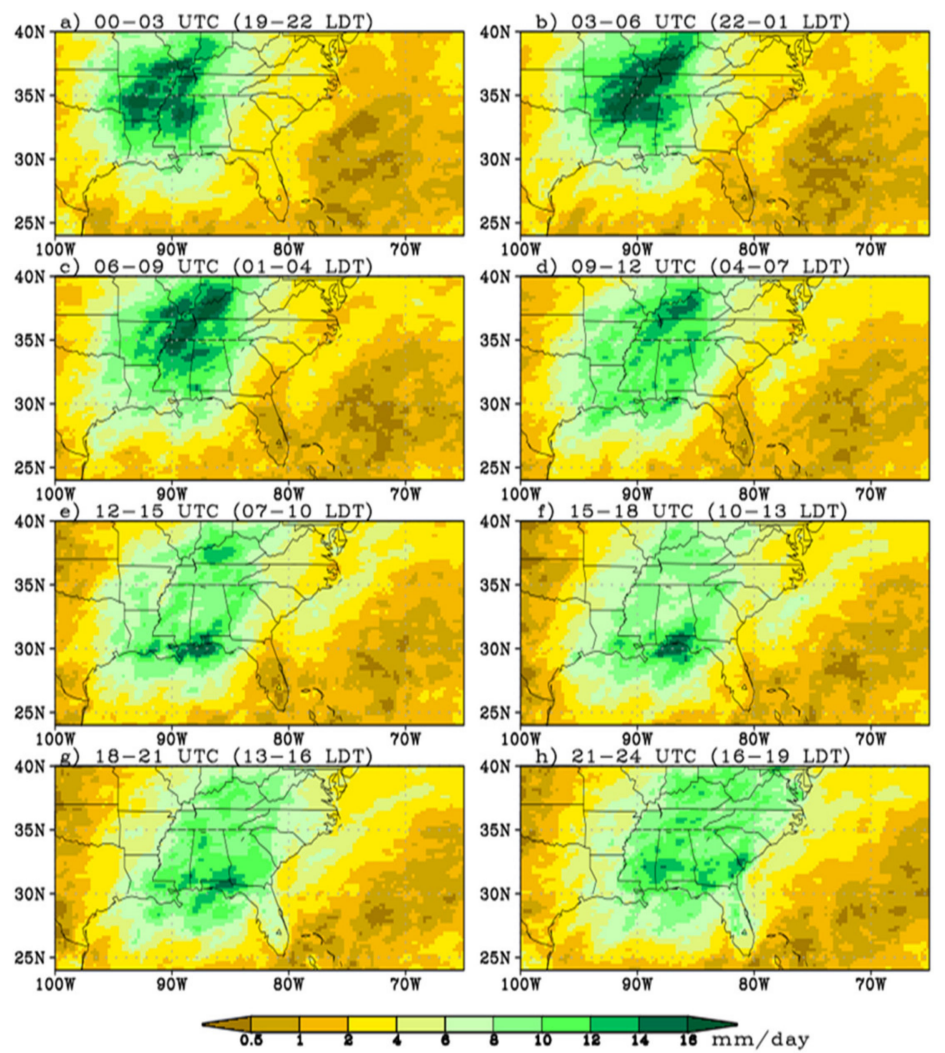

Figure 9. Same as Figure 7, but for WT3.

WT4 (FHZ) is a summer WT with westerly winds on $850 \mathrm{hPa}$ in the SEUS, which is also quite dry, but the diurnal cycle is very strong in the coastal area of the SEUS (Figure 10). In Florida, peak rainfall is in the afternoon (16:00-19:00 LDT), caused by the convergence of sea breezes from the east and west coast of the peninsula, or the so-called cumulus-merger process [40]. Along the Gulf coast where the wind is light, rainfall emerges over land in 13:00-16:00 LDT. But on the east coast with moderate offshore winds, the maximum rainfall occurs in 16:00-19:00 LDT, slightly later than that on the Gulf coast. Rainfall is over the ocean in the vicinity of the Gulf stream after midnight and in the morning.

In WT5 (AH) (Figure 11), which mostly occurs in late summer to autumn, the winds over the SEUS are quiescent. The diurnal cycle of precipitation is very strong in Florida, and the rainfall converges toward the center of the Peninsula from 13:00 LDT to 19:00 LDT, again indicating the cumulus-merger process [40]. The Gulf coast and east coast have light coastal rain in the afternoon, probably due to sea breezes in some days. Off the Carolina coast, rainfall peaks in the morning. An anticyclonic circulation on $850 \mathrm{hPa}$ sits over the SEUS in WT6 $(\mathrm{CH})$, with easterly winds over Florida and offshore westerly winds over northern SEUS (Figure 3f). The whole region is quite dry (Figure 12), but a moderately 
strong diurnal cycle still exists in Florida, and the peak rainfall is on the west coast of the peninsula, downwind of the $850 \mathrm{hPa}$ winds there. This is similar to the wake effect found in Borneo Island [41] and in Malay Peninsula and Sumatra Island [37]. The western Gulf coast, where onshore winds bring moisture, gets peak rainfall in the afternoon (13:00-16:00 LDT) and this extends all the way inland to the north in 16:00-19:00 LDT. On the east coast, it is very dry overnight, especially near the Appalachian Mountains, but there is still some rain near the coast, probably due to occasional sea breezes.

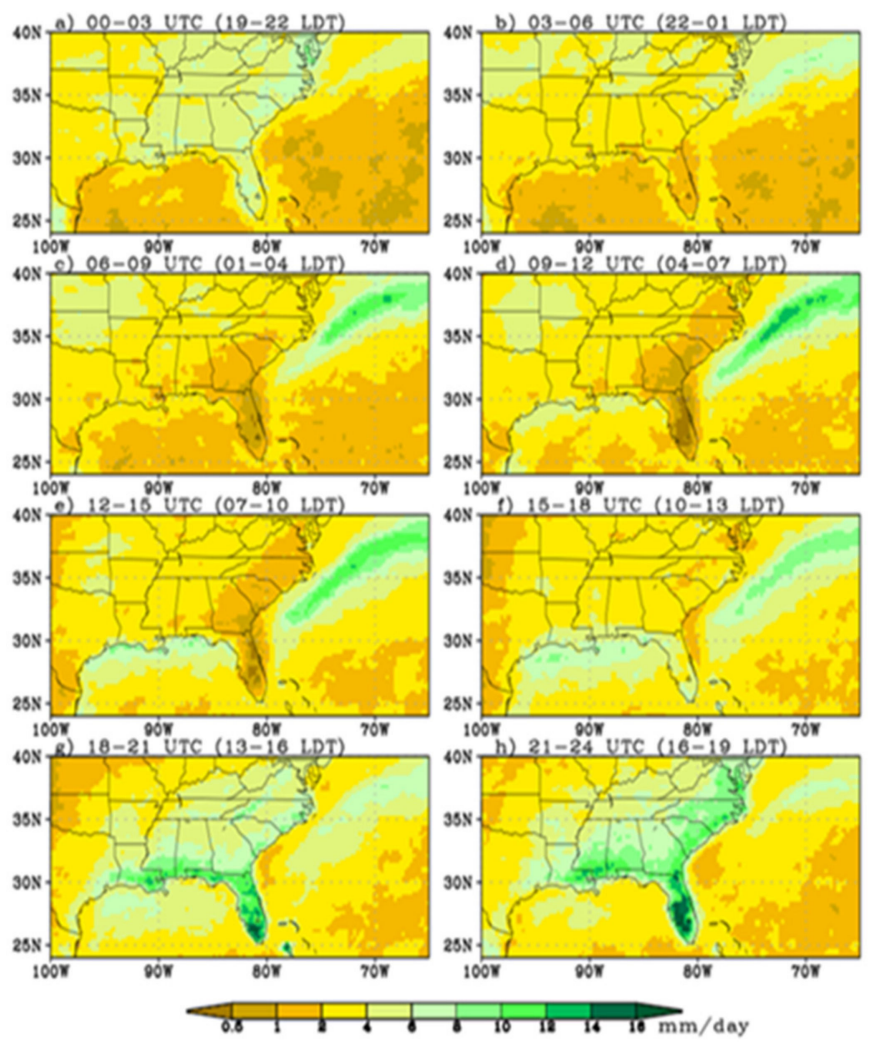

Figure 10. Same as Figure 7, but for WT4.

Because of the special topography of coastal plains and the Florida peninsula, the diurnal cycle of precipitation in the SEUS in the warm season is generally quite strong and behaves differently among the WTs. The maximum precipitation occurs in late afternoon, with an exception for WT3 that peaks at midnight in the Mississippi and Ohio River basin.

In the southeast coastal plain, we chose a domain in the Savannah River basin $\left(80.7-82.7^{\circ} \mathrm{W}, 32.4-34.4^{\circ} \mathrm{N}\right)$ and plotted the diurnal cycle of the average CMORPH precipitation in this domain for the six WTs (Figure 13). WT1, 3, 4 and 5 (ECT, PT, FHZ and $\mathrm{AH})$ have relatively heavy precipitation, thus their magnitudes of the diurnal cycle of precipitation are also rather large. In WT2 and 6 (MRVR and $\mathrm{CH}$ ), the Savannah River basin is quite dry, but they still have considerable diurnal cycle of precipitation, with maximum rain rate in 21-03 UTC (corresponding to 17-23 LDT). Indeed, [13] found that the percentage of days with sea breezes in WT2 and WT4 are higher than in other WTs, indicating the land-sea differential heating by the solar radiation in fair weather is the major cause for sea breezes. 

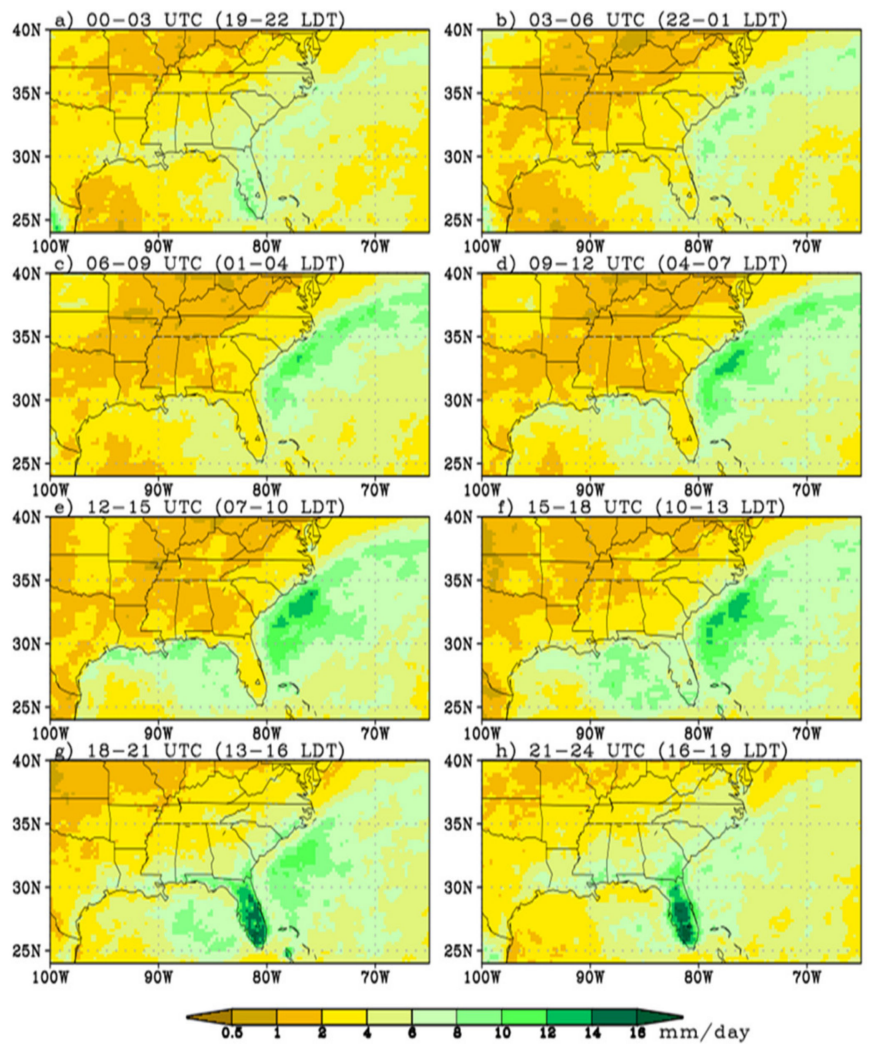

Figure 11. Same as Figure 7, but for WT5.
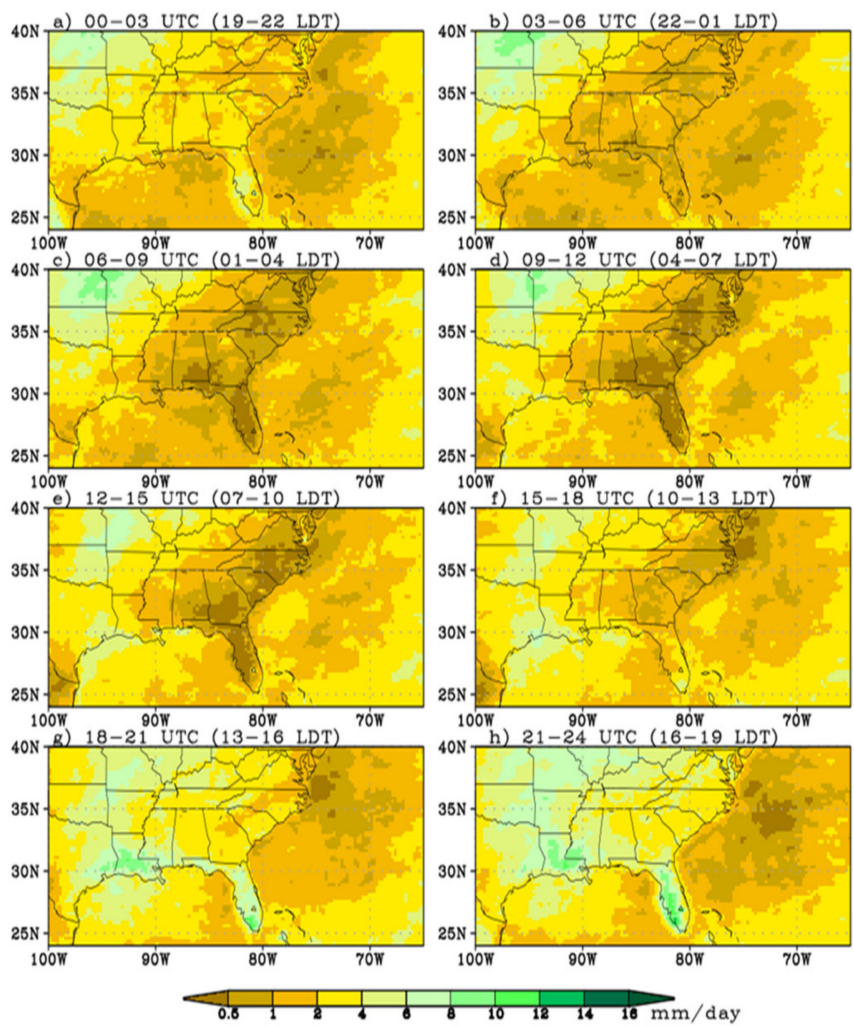

Figure 12. Same as Figure 7, but for WT6. 


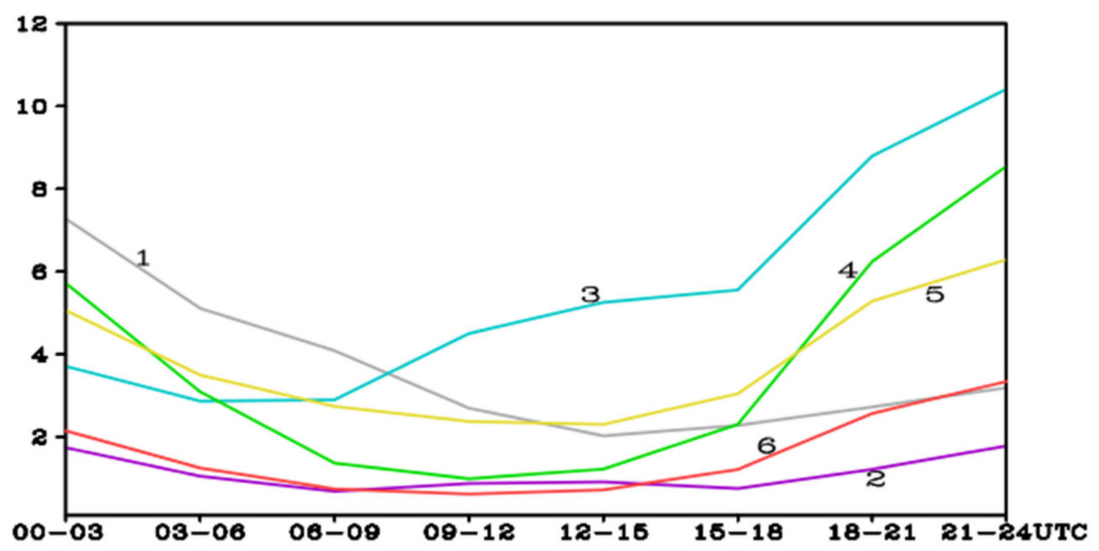

Figure 13. The mean diurnal cycle of the CMORPH estimated rainfall (mm/day) in the rectangular area of $80.7-82.7^{\circ} \mathrm{W}, 32.4-34.4^{\circ} \mathrm{N}$, over the Savannah River basin. WTs 1-6 are gray, purple, light blue, green, yellow, and red, respectively, also noted by the numbers 1-6.

\subsection{ENSO Impacts on the Rainfall in the SEUS}

ENSO affects seasonal precipitation in the SEUS, with above normal precipitation in the boreal winter and spring of warm ENSO (El Niño) years [42,43]. The frequencies of the WTs in El Niño, La Niña, and normal years in the spring months (March-May) in the ENSO ending year are shown in Figure 14. The frequencies of WT1, 2 and 3 all increase in El Niño years, and WT 4 and 6 are less frequent in El Niño years. The frequencies of WT2 and WT3 decrease in La Niña years. As discussed earlier, WTs 1-3 are with transient wave-like weather types in the mid-latitude westerlies. More frequent baroclinic WTs produce more precipitation in the SEUS, as shown in the anomaly precipitation map of the GHCN station data in El Niño years (Figure 15). Nieto Ferreira et al. [44] also found stronger mid-latitude cyclones and more intense precipitation over a large area in the SEUS during El Niño than La Niña and normal years. In contrast, negative rainfall anomalies are found in the SEUS in La Niña years. Therefore, the current result is consistent with previous results but interpreted from a dynamic view of the daily WTs. The Mississippi and Ohio River valley receives above normal rainfall in the spring of El Niño years, as shown in Figure 15. This can be pinpointed to the contribution of more frequent WT3 (PT) with a nocturnal rainfall maximum.

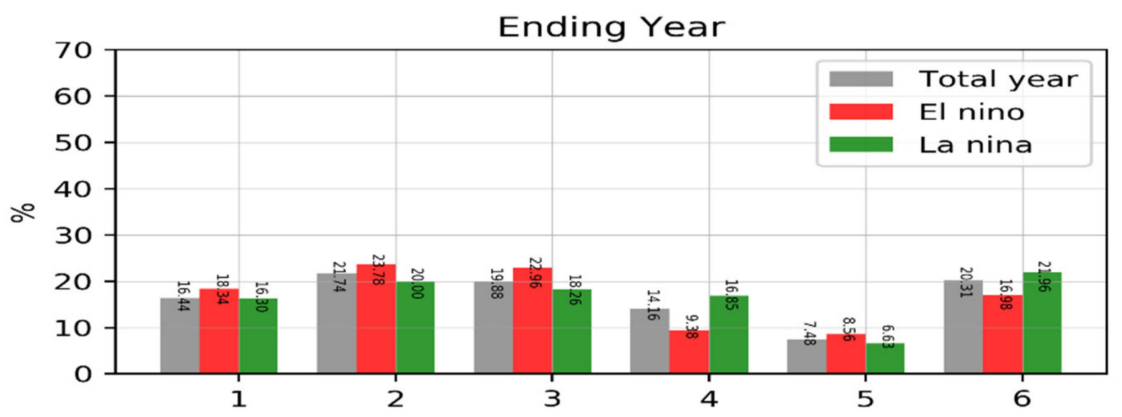

Figure 14. Frequencies of the WTs in all years (grey), El Niño years (red), and La Niña years (green) in March-May following the ENSO peak (i.e., in the ENSO ending year, MAM1). 

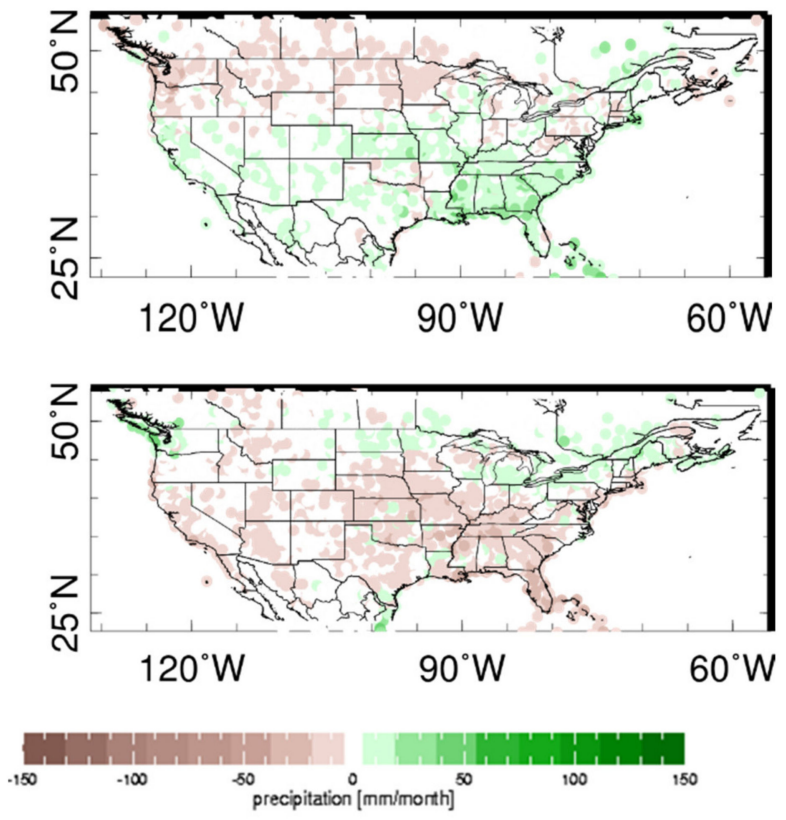

Figure 15. Precipitation anomalies in El Niño (top) and La Niña (bottom) years in the March-May following the ENSO peak (MAM1).

\section{Conclusions and Discussion}

The circulation-based daily weather typing analysis has been carried out for the SEUS and successfully delineated different WTs in the region. Among the six WTs in the warm season, three of them (WTs 1-3, ECT, MRVR, PT) are mid-latitude wave-like synoptic system propagating eastward, and the other three (WTs 4-6, FHZ, AH, CH) are closely associated with the NASH. WTs 1-3 occurs more frequently in the spring and fall, with the favorite progression loop of WT1 to WT2, then to WT3, and then back to WT1, with short persistence, indicating fast moving baroclinic waves. WTs 4-6 are long persistent. For instance, WT4 is a summer pattern prevailing in June-August with the NASH extended to SEUS, which can persist for days and even up to three weeks. The spatial pattern and temporal evolution of the WTs are consistent with regional climate variation. It gives a straightforward but more detailed weather-within-climate information beyond the conventional monthly or seasonal means. This WT information can be used for further investigation of climate variability and change in the SEUS from sub-seasonal to longer time scale.

In the warm season in the SEUS with long coastlines, sea breezes are quite common $[13,45]$. Therefore, the diurnal cycle of precipitation is also analyzed for each WT. In WT1, peak rainfall is at night over the warm Gulf stream area off the U.S. east coast. Peak rainfall is also overnight in the middle Mississippi and Ohio River valley in WT3. The diurnal cycle of precipitation is strong in Florida peninsula, especially in WTs prevalent in the late warm month (WTs 4, 5, and 6), indicating the role of convergence of sea breezes from east and west coast over the Florida peninsula, and the synoptic background winds determines the location of the maximum rainfall being on the center of the peninsula or propagated to the downwind direction. The diurnal cycle of rainfall is also seen on the Gulf coast in WTs 3, 4, 5, and 6. In WT3, the rainfall in Gulf coast during the daytime can propagate downwind to Georgia and South Carolina in the evening (Figures 9 and 13). On the east coast, the diurnal cycle can be seen in WT1, but rain peaks overnight; in other WTs, it peaks in the afternoon. The diurnal cycle is strong when the ambient winds are weak, such as WT5 in which winds in the SEUS are quiescent. Sea breezes, however, usually develop in fair weather days when the land-sea differential heating caused by the solar radiation is strong. Indeed, there are more percentage of days of sea breezes in the Savannah River basin in WT2 and 6, which are dry WTs, as found in [13]. 
We also checked the utility of the WTs in interpreting climate variability, taking the interannual variability of ENSO as an example. In El Niño years, there are more frequent WTs 1-3, which are associated with mid-latitude ridges and troughs. Accordingly, the rainfall in the SEUS is above normal. Rainfall is not only increased over the southeast coast, but also increased in the area such as Tennessee, indicating the strengthened moisture transport such as by the low-level flow in WT3. The positive precipitation anomaly in the Mississippi and Ohio River valley is also caused by more frequent WT3 with a nocturnal rainfall maximum in the area. Therefore, the current study advances the knowledge of climate variability by pinpointing to the contribution of certain WTs. The CMORPH data is good enough for the WT analysis but is not sufficiently long for the ENSO-composite analysis. Whether nocturnal rainfall is more frequent in El Niño years, as indicated by more frequent WT3, warrants further investigation. ENSO usually peaks in boreal winter. It may be worthwhile to extend this work from the warm season to the cold season, so that we have a year-round data for a complete ENSO impact analysis.

The WT analysis generated a calendar-like table for the warm season in the last four decades, with each day being assigned with one of the six WTs. This WT table can be used for studying other weather-relevant phenomena as long as the daily weather-relevant data are available. For example, how clouds, aerosols and radiation vary among the six WTs may affect electricity usage and green energy generation, which may further impact environment, economy and people's livelihood.

As for the prediction of the WTs, physically based numerical modeling outputs are still needed. First, the WT analysis method could be applied to the model hindcasts, and the modeled WTs be compared to the corresponding WTs from reanalysis data. If they match, the model is proved to be capable of capturing synoptic systems in the region. Then the model forecasts can be used for the WT forecast. Otherwise, some sort of calibration is needed for further investigation. By the way, the comparison of modeled and observed WTs should be a good way for model validation.

Author Contributions: Conceptualization, J.-H.Q., B.V., S.N. and D.W.; methodology, J.-H.Q.; validation, B.V., S.N. and D.W.; formal analysis, J.-H.Q.; writing-original draft preparation, J.-H.Q.; writing-review, J.-H.Q., B.V., S.N. and D.W. project administration, S.N.; funding acquisition, S.N. All authors have read and agreed to the published version of the manuscript.

Funding: This work was supported by the Laboratory Directed Research and Development (LDRD) program within the Savannah River National Laboratory (SRNL). This document was prepared in conjunction with work accomplished under Contract No. DE-AC09-08SR22470 with the U.S. Department of Energy (DOE) Office of Environmental Management (EM).

Institutional Review Board Statement: Not applicable.

Informed Consent Statement: Not applicable.

Data Availability Statement: The data presented in this study are available on request from the corresponding author. The data are not publicly available due to database access restrictions.

Acknowledgments: We appreciate the constructive comments by the three anonymous reviewers which greatly improved the paper.

Conflicts of Interest: The authors declare no conflict of interest.

\section{References}

1. Labosier, C.F.; Quiring, S.M. Hydroclimatology of the Southeastern USA. Clim. Res. 2013, 57, 157-171. [CrossRef]

2. Skeeter, W.; Senkbeil, J. Mid-tropospheric flow characteristics of intense precipitation events in the southeastern USA. Int. J. Appl. Geospat. Res. 2020, 11, 10-23. [CrossRef]

3. Skeeter, W.J.; Senkbeil, J.C.; Keellings, D.J. Spatial and temporal changes in the frequency and magnitude of intense precipitation events in the southeastern United States. Int. J. Clim. 2018, 39, 769-782. [CrossRef]

4. Powell, E.J.; Keim, B.D. Trends in daily temperature and precipitation extremes for the southeastern United States: 1948-2012. J. Clim. 2015, 28, 1592-1612. [CrossRef] 
5. Moore, B.J.; Mahoney, K.M.; Sukovich, E.M.; Cliffli, R.; Hamill, T.M. Climatology and environmental characteristics of extreme precipitation events in the southeastern United States. Mon. Wea. Rev. 2015, 143, 718-741. [CrossRef]

6. Lorenz, E.N. Deterministic nonperiodic flow. J. Atmos. Sci. 1963, 20, 130-141. [CrossRef]

7. Sheridan, S.C. The development of a weather-type classification scheme for North America. Int. J. Clim. 2002, 22, 51-68. [CrossRef]

8. Lee, C.C. The gridded weather typing classification version 2: A global scale expansion. Int. J. Clim. 2020, 40, 1178-1196. [CrossRef]

9. Roller, C.D.; Qian, J.-H.; Agel, L.; Barlow, M.; Moron, V. Winter weather regimes in the Northeast United States. J. Clim. 2016, 29, 2963-2980. [CrossRef]

10. Coe, D.; Barlow, M.; Agel, L.; Colby, F.; Skinner, C.; Qian, J.-H. Clustering analysis of autumn weather regimes in the Northeast U.S. J. Clim. 2021, 1, 1-52. [CrossRef]

11. Qian, J.-H.; Robertson, A.W.; Moron, V. Interaction among ENSO, the monsoon and diurnal cycle in rainfall variability over Java, Indonesia. J. Atmos. Sci. 2010, 67, 3509-3524. [CrossRef]

12. Agel, L.; Barlow, M.; Qian, J.-H.; Colby, F.; Douglas, E.; Eichler, T. Climate of daily precipitation and extreme precipitation in the Northeast United States. J. Hydrometeorol. 2015, 16, 2537-2557. [CrossRef]

13. Viner, B.; Noble, S.; Qian, J.-H.; Werth, D.; Gayes, P.; Pietrafesa, L.; Bao, S. 2021: Frequency and Characteristics of Inland Advecting Sea Breezes in the Southeast United States. Atmosphere 2021, 12, 950. [CrossRef]

14. Diem, J.E. Synoptic-scale controls of summer precipitation in the Southeastern United States. J. Clim. 2006, 19, 613-621. [CrossRef]

15. Diem, J.E.; Hursey, M.A.; Morris, I.R.; Murray, A.C.; Rodriguez, R.A. Upper-level atmospheric circulation patterns and groundlevel ozone in the Atlanta Metropolitan area. J. Appl. Meteorol. Clim. 2010, 49, 2185-2196. [CrossRef]

16. Diem, J.E. Influences of the Bermuda High and atmospheric moistening on changes in summer rainfall in the Atlanta, Georgia region, USA. Int. J. Clim. 2013, 33, 160-172. [CrossRef]

17. Bentley, M.L.; Stallins, J.A.; Ashley, W.S. Synoptic environments favorable for urban convection in Atlanta, Georgia. Int. J. Clim. 2012, 32, 1287-1294. [CrossRef]

18. Michelangeli, P.-A.; Vautard, R.; Lagras, B. Weather regimes: Recurrence and quasi-stationarity. J. Atmos. Sci. 1995, 52, 1237-1256. [CrossRef]

19. Moron, V.; Robertson, A.W.; Qian, J.-H.; Ghil, M. Weather types across the Maritime Continent: From the diurnal cycle to interannual variations. Front. Environ. Sci. 2015, 2, 65. [CrossRef]

20. Carbone, R.E.; Tuttle, J.D.; Ahijevych, D.A.; Trier, S.B. Inferences of predictability associated with warm season precipitation episodes. J. Atmos. Sci. 2002, 59, 2033-2056. [CrossRef]

21. Carbone, R.E.; Tuttle, J.D. Rainfall occurrence in the U.S. warm season: The diurnal cycle. J. Clim. 2008, 21, 4132-4146. [CrossRef]

22. Bell, G.D.; Bozart, L.F. Appalachian cold-air damming. Mon. Wea. Rev. 1988, 116, 137-161. [CrossRef]

23. Rackley, J.A.; Knox, J.A. A climatology of southern Appalachian cold-air damming. Weather Forecast. 2016, 31, 419-432. [CrossRef]

24. Parker, M.D.; Ahijevych, D.A. Convective episodes in the east-central United States. Mon. Wea. Rev. 2007, 135, 3707-3727. [CrossRef]

25. Shepherd, J.M.; Grundstein, A.; Mote, T.L. Quantifying the contribution of tropical cyclones to extreme rainfall along the coastal southeastern United States. Geophys. Res. Lett. 2007, 34, L23810. [CrossRef]

26. Knight, D.B.; Davis, R.E. Climatology of tropical cyclone rainfall in the southeastern United States. Phys. Geogr. 2007, 28, 126-147. [CrossRef]

27. Brun, J.; Barros, A.P. Mapping the role of tropical cyclones on the hydroclimate of the southeast United States: 2002-2011. Int. J. Climatol. 2014, 34, 494-517. [CrossRef]

28. Zhou, Y.; Matyas, C.J. Spatial characteristics of storm total rainfall swaths associated with tropical cyclones over the eastern United States. Int. J. Climatol. 2017, 37, 557-569. [CrossRef]

29. Li, L.; Li, W.; Kushnir, Y. Variation of the North Atlantic subtropical high western ridge and its implication to southeastern US summer precipitation. Clim. Dyn. 2012, 39, 1401-1412. [CrossRef]

30. Keim, B.D. Spatial, synoptic, and seasonal patterns of heavy rainfall in the Southeastern United States. Phys. Geogr. 1996, 17, 313-328. [CrossRef]

31. Senkbeil, J.C.; Brommer, D.M.; Comstock, I.J. Hydrometeorological application of an extratropical cyclone classification scheme in the southern United States. Theor. Appl. Clim. 2012, 109, 27-38. [CrossRef]

32. Konrad, C.E. Synoptic features associated with heavy rainfall over the interior southeastern United States. Weather Forecast. 1997, 12, 553-567. [CrossRef]

33. Lee, C.C. The development of a gridded weather typing classification scheme. Int. J. Clim. 2015, 35, 641-659. [CrossRef]

34. Kalnay, E.; Kanamitsu, M.; Kistler, R.; Collins, W.; Deaven, D.; Gandin, L.; Iredell, M.; Saha, S.; White, G.; Woollen, J.; et al. The NCEP/NCAR 40-year reanalysis project. Bull. Amer. Meteor. Soc. 1996, 77, 437-471. [CrossRef]

35. Xie, P.; Joyce, R.; Wu, S.; Yoo, S.-H.; Yarosh, Y.; Sun, F.; Lin, R. Reprocessed, bias-corrected CMORPH global high-resolution precipitation estimates from 1998. J. Hydrometeorol. 2017, 18, 1617-1641. [CrossRef]

36. Moron, V.; Robertson, A.W.; Ward, N.; Ndiaye, O. Weather types and rainfall over Senegal, Part I: Observed analysis. J. Clim. 2008, 21, 266-287. [CrossRef]

37. Qian, J.-H. Multi-scale climate processes and rainfall variability in Sumatra, Peninsula Malaysia and Singapore associated with ENSO in boreal fall and winter. Int. J. Climatol. 2020, 40, 4171-4188. [CrossRef] 
38. Qian, J.-H.; Tao, W.-K.; Lau, K.-M. Mechanisms for torrential rain associated with the Mei-yu development during SCSMEX 1998. Mon. Wea. Rev. 2004, 132, 3-27. [CrossRef]

39. Blackadar, A.K. Boundary layer wind maxima and their significance for the growth of nocturnal inversions. Bull. Am. Meteorol. Soc. 1957, 38, 283-290. [CrossRef]

40. Simpson, J.; Westcott, N.E.; Clerman, R.J.; Pielke, R.A. On cumulus mergers. Arch. Meteor. Geophys. Bioklim. 1980, $29,1-40$.

41. Qian, J.-H.; Robertson, A.W.; Moron, V. Diurnal cycle in different weather regimes and rainfall variability over Borneo associated with ENSO. J. Clim. 2013, 26, 1772-1790. [CrossRef]

42. Mo, K.C. Interdecadal modulation of the impact of ENSO on precipitation and temperature over the United States. J. Clim. 2010, 23, 3639-3656. [CrossRef]

43. Engstrom, J.; Waylen, P. Drivers of long-term precipitation and runoff variability in the southeastern USA. Theor. Appl. Clim. 2018, 131, 1133-1146. [CrossRef]

44. Nieto Ferreira, R.; Hall, L.; Richenbach, T.M. A climatology of the structure, evolution, and propagation of midlatitude cyclones in the Southeast United States. J. Clim. 2013, 26, 8406-8421. [CrossRef]

45. Buckley, R.; Kurzeja, R.J. An observational and numerical study of the nocturnal sea breeze. J. Appl. Met. 1997, 36, 531-546. 